\title{
Environmental costs resulting from the use of hard coal to electricity generation in Poland
}

\author{
Katarzyna Stala-Szlugaj ${ }^{1, *}$, and Zbigniew Grudziński ${ }^{2}$ \\ ${ }^{1}$ Ph.D. Eng., The Mineral and Energy Economy Research Institute, Polish Academy of Sciences, Wybickiego 7A, 31-261 \\ Cracow, Poland \\ ${ }^{2}$ D. Sc., Eng., Associate Professor; The Mineral and Energy Economy Research Institute, Polish Academy of Sciences, \\ Wybickiego 7A, 31-261 Cracow, Poland
}

\begin{abstract}
In the world's fuel mix used for generating electricity, the most common fossil fuel is coal. In the EU, coal combustion and electricity generation entail the need to purchase emission allowances (EUA) whose purchase costs affect the costs of electricity generation significantly. The research described in the article shows how current market conditions shape the profitability of generating electricity from coal and how Clean Dark Spread (CDS) changes as a function of changes in energy and coal prices at the assumed levels of emission and prices of EUA allowances. The article compares the results of CDS calculations in two variants. Areas have been highlighted where prices of both coal and EUA allowances cause CDS to assume values at which the prices of generated electricity do not cover the costs of fuel (i) and $\mathrm{CO}_{2}$ emission allowances, cover all costs (ii), or constitute positive prices (iii), but still do not cover all fixed costs. With higher power plant efficiency, $\mathrm{CO}_{2}$ emissions are lower $(0.722 \mathrm{t} / \mathrm{MWh})$. The costs of purchasing fuel required to generate $1 \mathrm{MWh}$ of electricity are also lower. In such case - even with relatively high prices of coal - a power plant can achieve profitability of electricity generation.
\end{abstract}

\section{Introduction}

In the world's fuel mix, for years, coal has had the biggest share among fuels used for generating electricity. According to [1], in 2015, the share of coal was $40 \%$, and coal was used to generate $9,639 \mathrm{TWh}$ of electricity (Fig. 1). The second place is occupied by natural gas $(22 \%)$ and the third one-by water (16\%). To compare, in the 6,131 TWh of electricity produced in 1973 [2], the share of coal was lower by 3 percentage points, the second place went to petroleum and petroleum products $(25 \%)$, and the third one-also to water $(21 \%)$. Fig. 2 shows the share of coal power industry (both hard coal and brown coal) in the energy mix of selected countries in 2015.

The following countries (Fig. 2) have the highest share of coal power generation in the world: Kosovo (97\% in 2014), South Africa (90\%), and Poland (79\%). On a global scale, coal power generation (including both hard coal and brown coal) amounted to $40 \%$ of total electricity production.

In the Polish power system, coal (both hard and brown) is the primary solid fuel used to generate electricity. Between 2010 and 2015, electricity generation in Poland increased by 5\% (from 157.7 to 164.9 TWh [3]). In coal-fired power plants (including both hard coal and brown coal), there has been a $4 \%$ drop (from 136.5 to $130.5 \mathrm{TWh}$ ). In the case of hard coal-fired power plants, the share decreased by 8.6 percentage points; production dropped by $10.1 \mathrm{TWh}$ and amounted to 77.7 TWh in 2015. Brown coal-fired power plants achieved a growth (by 1.2 percentage points). Their electricity generation increased to $52.8 \mathrm{TWh}$.

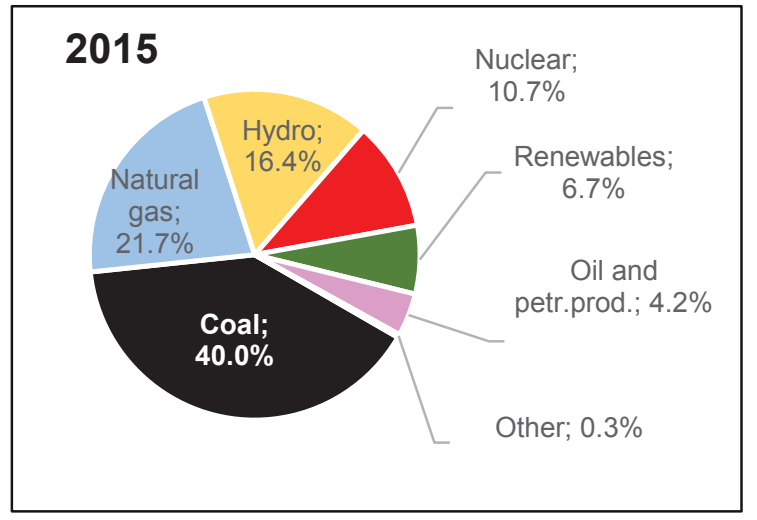

Fig. 1. Worldwide breakdown of electricity generation by fuel in 2015 [1].

However, coal combustion is often associated with the emission of various pollutants: e.g. $\mathrm{CO}_{2}, \mathrm{SOx}, \mathrm{NOx}$, particular matter (PM), and fly ash $[4,5,6])$. In the case of electricity generation, it is often necessary to carry out many simulations to calculate fuel and environmental costs $[7,8]$.

The article aims is to present simulation calculations that will show changes in the theoretical producer's margin (CDS-Clean Dark Spread) at the assumed prices of coal and electric energy.

\footnotetext{
* Corresponding author: kszlugaj@min-pan.krakow.pl
} 


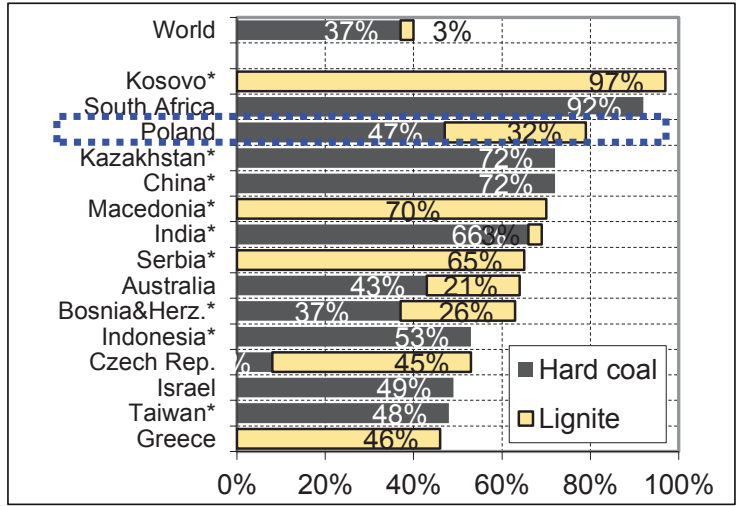

Fig. 2. Share of coal in the energy mix of selected countries of the world in 2015 (* in 2014) [1].

\section{$2 \mathrm{CO}_{2}$ emissions in the world}

In 2015, worldwide emissions of $\mathrm{CO}_{2}$ amounted to 36.2 billion $\mathrm{t}$ (Fig. 3). Even though this number is higher than in 1990 by $59 \%$ (or 13.5 billion $\mathrm{tCO}_{2}$ ), it was the first time when a decline in comparison with the previous year occurred (by $-0.3 \%$, i.e. 0.1 billion $\mathrm{tCO}_{2}$ ). A slowdown in the growth of emissions has been observed since 2013.

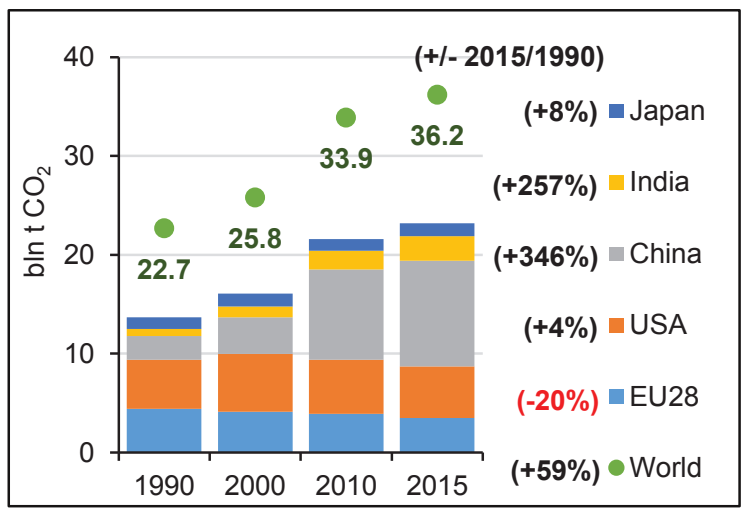

Fig. 3. $\mathrm{CO}_{2}$ emissions by selected country, 1990-2015 (own work based on [9]).

In the case of EU28 countries, emissions decreased by $20 \%\left(0.9\right.$ billion $\left.\mathrm{tCO}_{2}\right)$ compared to 1990 and amounted to 3.5 billion $\mathrm{tCO}_{2}$ in 2015 (Fig. 4).

Asia's strong industrial growth and transferring energy-intensive industry to this part of the world by global corporations contribute to a large increase in $\mathrm{CO}_{2}$ emissions. For example, in China, it increased by as much as $346 \%$ (by 8.3 billion $\mathrm{tCO}_{2}$ ), and in India-by $257 \%$ ( 1.8 billion $\mathrm{tCO}_{2}$ ).

Worldwide $\mathrm{CO}_{2}$ emissions per capita amounted to $4.9 \mathrm{t}$ in 2015, which constitutes an increase by $14 \%$ compared to 1990. The highest increase of emissions was observed in: China $\left(285 \%, 7.7 \mathrm{tCO}_{2} /\right.$ capita in 2015) and Malaysia $\left(170 \%, 8.1 \mathrm{tCO}_{2} /\right.$ capita in 2015). In the EU28 countries, it decreased by $25 \%$ compared to 1990 and amounted to $6.9 \mathrm{tCO}_{2} /$ capita. In Poland, this emission is lower than in the Netherlands and Germany. In 2015, it amounted to $7.6 \mathrm{tCO}_{2} /$ capita, which constitutes a decrease by $20 \%$ compared to 1990 and by $10 \%$ compared to 2010 .
One of the major sources of $\mathrm{CO}_{2}$ emissions is heat and electricity generation (Fig. 5). This industry contributed to $42 \%$ of the global $\mathrm{CO}_{2}$ emissions (13.6 billion t) in 2014 .

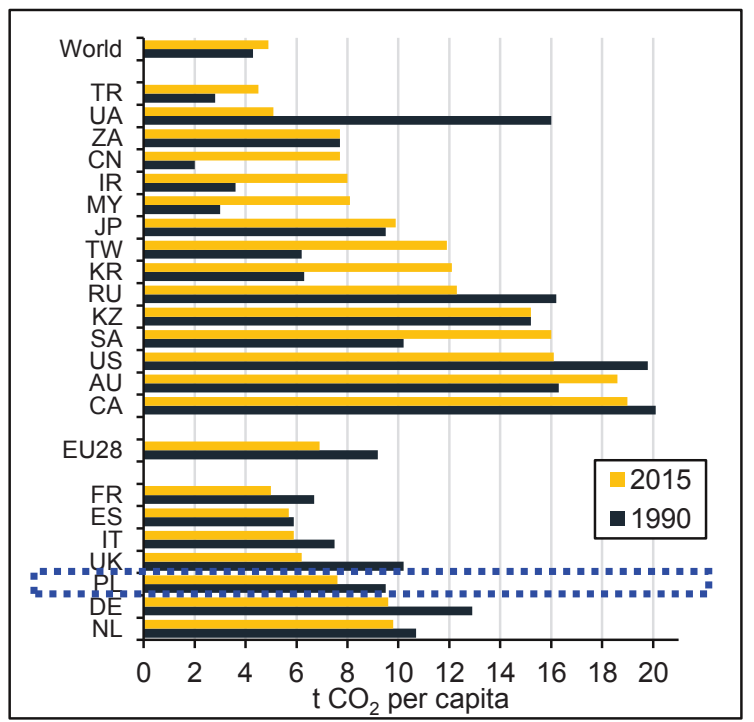

Fig. 4. $\mathrm{CO}_{2}$ emissions by selected country, $\mathrm{tCO}_{2} /$ capita (own work based on [9]).

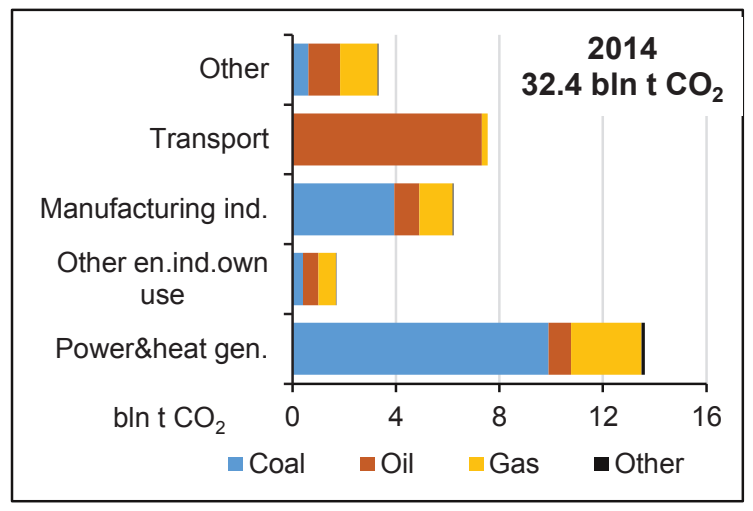

Fig. 5. World $-\mathrm{CO}_{2}$ emissions by sectors, 2014 [10].

Coal is one of the fuels that are used to generate electricity and have the largest impact on $\mathrm{CO}_{2}$ emissions. In 2014, coal-fired power plants accounted for $31 \%$ of worldwide $\mathrm{CO}_{2}$ emissions (9.9 billion $\mathrm{tCO}_{2}$ ).

\section{Assessment of the influence of the prices of $\mathrm{CO}_{2}$ emission allowances on the prices of electricity}

The costs related to $\mathrm{CO}_{2}$ emissions are an important factor influencing electricity prices. The costs of purchasing $\mathrm{CO}_{2}$ emission allowances will have an increasing share in the costs of electricity generation. This is caused by the high $\mathrm{CO}_{2}$ emissions associated with generating electricity from coal compared to other energy carriers. For the EU, reducing $\mathrm{CO}_{2}$ emissions is the main priority of the climate policy $[11,12,13,14]$. This makes the events related to the $\mathrm{CO}_{2}$ emission allowances trading market extraordinarily important for the power industry in Poland. These events affect the 
assessment of the competitiveness of coal compared to other fuels.

In Europe, an emissions trading system has been introduced following the implementation of Directive 2003/87/EC (the so-called ETS Directive) and Directive 2009/29/EC that improves the EU ETS system. This market has been functioning since January 2005, currently within the so-called third trading period (20132020). The participation in the system is mandatory for the types of business activities specified in the directive. Emission allowances are tradable both on exchanges and on the over-the-counter market. They can also be sold or purchased on the basis of commercial agreements with any company [15].

The most liquid market of derivatives for $\mathrm{CO}_{2}$ emission allowances is the European Climate Exchange (ICE-ECX) based in London. Fig. 6 presents monthly average (spot) price changes of EUA emission allowances (ICE-ECX exchange) in $\mathrm{EUR} / \mathrm{tCO}_{2}$ in the years 2006-2017. The diagram also shows the dates of individual emission allowance trading periods (20052007, 2008-2012, 2013-2020). Companies subject to the emissions trading system must acquire allowances that decrease in number in each trading period. The price level of emission allowances in the third trading period is approx. 4.3-8.5 EUR/t.

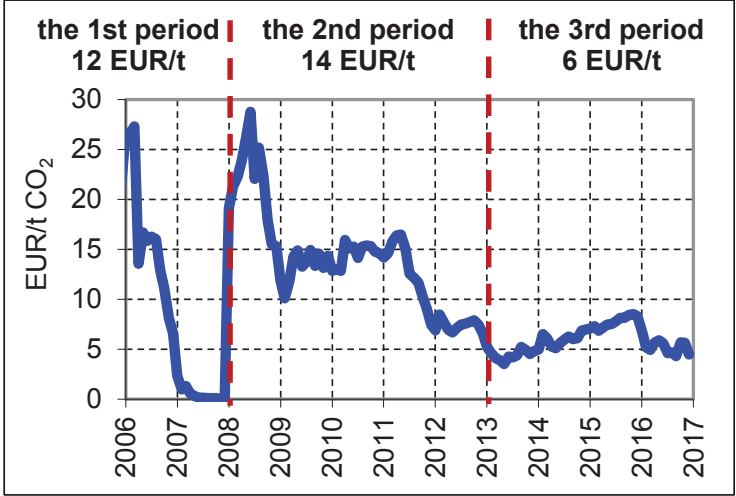

Fig. 6. Average monthly prices of EUA emission allowances (ICE-ECX), EUR/ $/ \mathrm{tCO}_{2}$ - futures contracts as of December of each year [16]).

In January 2017, Thomson Reuters (TR) analysts presented forecasts for the pricing of EUA allowances in the years 2017-2030, at nominal and real prices. Real (using 2015 as the base year) and nominal prices (Tab.1) [16].

According to the data presented, the prices of the allowances will increase. By 2020, there will be an increase of approx. 50\%. This will mainly be an effect of the Market Stability Reserve (MSR). The extent of its influence will depend on the allowance transfer ratio from auctions to the MSR reserve. The planned level of this indicator will be either $12 \%$ or $24 \%$.

As a result, the level of $\mathrm{CO}_{2}$ emission allowance prices will increasingly affect the level of electricity prices. This cost element can also significantly affect the price competitiveness between individual energy carriers. It may occur especially after it becomes necessary to acquire all $(100 \%)$ of the required $\mathrm{CO}_{2}$ emission allowances at market prices.

In order to investigate the impact of $\mathrm{CO}_{2}$ emission allowance prices on electricity generation costs, an analysis of the theoretical energy producer's margin (spread) has been carried out.

Table 1. Forecast for the pricing of EUA allowances in the years 2017-2030 by Thomson Reuters (* using 2015 as the base year) [16].

\begin{tabular}{|c|c|c|c|c|}
\hline Kind of Prices & 2017 & 2020 & 2025 & 2030 \\
\hline $\begin{array}{c}\text { Nominal } \\
\text { prices, EUA }\end{array}$ & 5.9 & 9.0 & 14.3 & 23.8 \\
\hline $\begin{array}{c}\text { Real prices* } \\
\text { EUA }\end{array}$ & 5.8 & 8.3 & 12.1 & 18.7 \\
\hline
\end{tabular}

Spread is defined as the difference between the market price of electricity and the price of fuel used to generate it, with due regard for the efficiency of the process (both figures must be expressed in the same units, e.g.: EUR/MWh, USD/GJ, PLN/MWh, etc.).

For coal, the term used is "Dark Spread"; for gas, it's "Spark Spread". If, when calculating the spread, the cost of $\mathrm{CO}_{2}$ emissions (related to a given fuel's combustion) is taken into account additionally, the word "Clean" is added to the spread name.

Therefore, "Clean Dark Spread" (CDS) is the theoretical producer's margin for generating energy from coal at market prices for energy, fuel, and emission allowances, calculated as a simple relation $[11,18]$ :

$$
C D S=C_{E E}-C_{W}-C_{C O 2} \quad[P L N / M W h]
$$

where:

- $\mathrm{C}_{\mathrm{EE}}$ - electricity energy price,

- $\mathrm{C}_{\mathrm{w}}$ - fuel purchase price,

- $\mathrm{C}_{\mathrm{CO} 2}$ - emission allowances price.

It can be assumed that the theoretical producer's margin should cover fixed costs of energy generation. Fig. 7 shows the changes in fixed costs in Polish hard coal-fired power plants in the years 2010-2016 as well as the changes in the PLN/USD exchange rate during this period. On the basis of this data, it can be assumed that the recent level of fixed costs is approx. 12.5 USD/MWh (50 PLN/MWh).

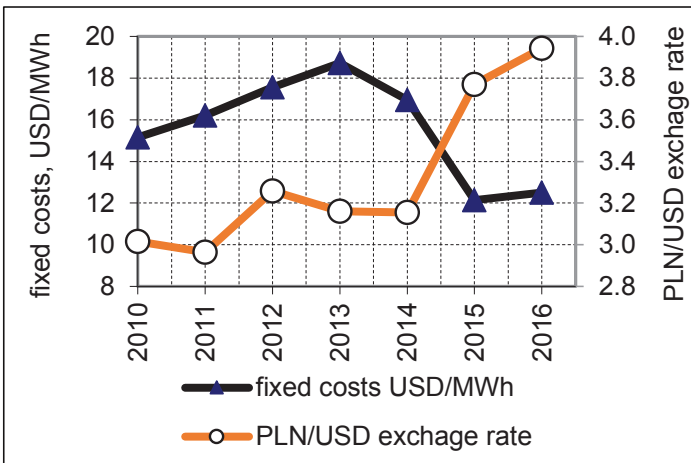

Fig. 7. Comparison of fixed costs in domestic hard and brown coal-fired power plants [19]. 
Table 2. Input data for CDS calculations-options 1 and 2.

\begin{tabular}{|c|c|c|}
\hline Parameter & Input data for calculation \\
\hline Electricity price & \multicolumn{2}{|c|}{$\begin{array}{c}35-50 \mathrm{USD} / \mathrm{MWh} \\
(150-200 \mathrm{PLN} / \mathrm{MWh})\end{array}$} \\
\hline Coal price & \multicolumn{2}{|c|}{$\begin{array}{c}1.72-3.50 \mathrm{USD} / \mathrm{GJ} \\
(7-15 \mathrm{PLN} / \mathrm{GJ})\end{array}$} \\
\hline Calorific value & $5500 \mathrm{kcal} / \mathrm{kg}(23 \mathrm{GJ} / \mathrm{kg})$ \\
\hline $\begin{array}{c}\text { Prices of allowances } \\
\text { for } \mathrm{CO}_{2} \text { emissions }\end{array}$ & $\begin{array}{c}\text { Calculations were made at two } \\
\text { levels: } 5 \text { and } 10 \mathrm{EUR} / \mathrm{ton} \mathrm{CO} 2\end{array}$ \\
\hline $\begin{array}{c}\text { Exchange rates } \\
\text { Power plant } \\
\text { efficiency }\end{array}$ & \multicolumn{2}{|c|}{$4.0 \mathrm{PLN} / \mathrm{USD}$ and } \\
\hline $\begin{array}{c}\mathrm{CO} \text { emission factor } \\
\text { (WE) - according to } \\
{[17]}\end{array}$ & $\begin{array}{c}92.3 \mathrm{~kg} / \mathrm{GJ}= \\
0.923\end{array}$ & $\begin{array}{c}92.3 \mathrm{~kg} / \mathrm{GJ}= \\
0.722\end{array}$ \\
$\mathrm{tCO} / \mathrm{MWh}$ & $\mathrm{tCO} / \mathrm{MWh}$ \\
\hline
\end{tabular}

Table 2 presents input data used for CDS calculations. The variability of the market prices of electricity in the range of 35-50 USD/MWh (140-200 PLN/MWh) has been assumed. The range of these prices is close to the average monthly spot prices at TGE (Polish Power Exchange) in the last 2 years. Coal prices vary in the range of $2-3.50 \mathrm{USD} / \mathrm{GJ}(8-15 \mathrm{PLN} / \mathrm{GJ})$. The net as received (NAR) calorific value of this coal is 5,500 $\mathrm{kcal} / \mathrm{kg}$ (approx. $23 \mathrm{MJ} / \mathrm{kg}$ ). This number is close to the average parameters of coal combusted by Polish power plants.

Recently, in international trade, a number of price indexes appeared for coal with decreased quality compared to the so-called standard coal $(6,000 \mathrm{kcal} / \mathrm{kg}$, NAR). One of them is $5,500 \mathrm{kcal} / \mathrm{kg}$ coal traded in such countries as Australia or South Africa [20].

Calculations have been made for two pricing levels of emission allowances: 5 and $10 \mathrm{EUR} / \mathrm{tCO}_{2}$, assuming that a power plant must buy $100 \%$ of required

Table 3. Results of simulation calculations of CDS at EUA price of $5 \mathbf{E U R} / \mathbf{t C O} \mathbf{O}_{2}$ and power plant efficiency of $36 \%$ and $46 \%$.

\begin{tabular}{|c|c|c|c|c|c|c|c|}
\hline \multirow{3}{*}{ Coal Price, USD/GJ } & \multicolumn{7}{|c|}{ Electricity price USD/MWh } \\
\hline & 35.0 & 37.5 & 40.0 & 42.5 & 45.0 & 47.5 & 50.0 \\
\hline & \multicolumn{7}{|c|}{ Power plant efficiency: $36 \%$} \\
\hline 2.00 & 10.2 & 12.7 & 15.2 & 17.7 & 20.2 & 22.7 & 25.2 \\
\hline 2.25 & 7.7 & 10.2 & 12.7 & 15.2 & 17.7 & 20.2 & 22.7 \\
\hline 2.50 & 5.2 & 7.7 & 10.2 & 12.7 & 15.2 & 17.7 & 20.2 \\
\hline 2.75 & 2.7 & 5.2 & 7.7 & 10.2 & 12.7 & 15.2 & 17.7 \\
\hline 3.00 & 0.2 & 2.7 & 5.2 & 7.7 & 10.2 & 12.7 & 15.2 \\
\hline 3.25 & -2.3 & 0.2 & 2.7 & 5.2 & 7.7 & 10.2 & 12.7 \\
\hline \multirow[t]{2}{*}{3.50} & -4.8 & -2.3 & 0.2 & 2.7 & 5.2 & 7.7 & 10.2 \\
\hline & \multicolumn{7}{|c|}{ Power plant efficiency: $46 \%$} \\
\hline 2.00 & 14.5 & 17.0 & 19.5 & 22.0 & 24.5 & 27.0 & 29.5 \\
\hline 2.25 & 12.5 & 15.0 & 17.5 & 20.0 & 22.5 & 25.0 & 27.5 \\
\hline 2.50 & 10.6 & 13.1 & 15.6 & 18.1 & 20.6 & 23.1 & 25.6 \\
\hline 2.75 & 8.6 & 11.1 & 13.6 & 16.1 & 18.6 & 21.1 & 23.6 \\
\hline 3.00 & 6.7 & 9.2 & 11.7 & 14.2 & 16.7 & 19.2 & 21.7 \\
\hline 3.25 & 4.7 & 7.2 & 9.7 & 12.2 & 14.7 & 17.2 & 19.7 \\
\hline 3.50 & 2.8 & 5.3 & 7.8 & 10.3 & 12.8 & 15.3 & 17.8 \\
\hline
\end{tabular}


allowances. Two levels of power plant efficiency have been assumed: $36 \%$ (variant I) and $46 \%$ (variant II). The results of the CDS calculations for these variants have been summarized in Tables 3 and 4.

Each of the result tables (Tables 3 and 4) for the two price levels of EUA emission allowances, 5 and 10 EUR/MWh, consists of two parts with different power plant efficiency: $36 \%$ in the upper part and $45 \%$ in the lower part. Calculation results are given in USD/MWh. The calculations have been carried out for coal prices emission allowances is approx. 12.5 USD/MWh in the case of hard coal-fired power plants.

In the result tables, the fields containing calculated CDS values of $\geq 12.5 \mathrm{USD} / \mathrm{MWh}$ are highlighted in bold. Such values mean that, at given prices of coal, electricity, and $\mathrm{CO}_{2}$ emission allowances, the producer will get a margin covering at least the fixed costs.

Negative figures mean that energy generation is completely unprofitable. With such parameters (input data), energy prices will not even cover the costs of fuel

Table 4. Results of simulation calculations of CDS at EUA price of $10 \mathrm{EUR} / \mathbf{t C O}$ and power plant efficiency of $36 \%$ and $46 \%$.

\begin{tabular}{|c|c|c|c|c|c|c|c|}
\hline \multirow{3}{*}{ Coal Price, USD/GJ } & \multicolumn{7}{|c|}{ Electricity price USD/MWh } \\
\hline & 35.0 & 37.5 & 40.0 & 42.5 & 45.0 & 47.5 & 50.0 \\
\hline & \multicolumn{7}{|c|}{ Power plant efficiency: $36 \%$} \\
\hline 2.00 & 5.3 & 7.8 & 10.3 & 12.8 & 15.3 & 17.8 & 20.3 \\
\hline 2.25 & 2.8 & 5.3 & 7.8 & 10.3 & 12.8 & 15.3 & 17.8 \\
\hline 2.50 & 0.3 & 2.8 & 5.3 & 7.8 & 10.3 & 12.8 & 15.3 \\
\hline 2.75 & -2.2 & 0.3 & 2.8 & 5.3 & 7.8 & 10.3 & 12.8 \\
\hline 3.00 & -4.7 & -2.2 & 0.3 & 2.8 & 5.3 & 7.8 & 10.3 \\
\hline 3.25 & -7.2 & -4.7 & -2.2 & 0.3 & 2.8 & 5.3 & 7.8 \\
\hline \multirow[t]{2}{*}{3.50} & -9.7 & -7.2 & -4.7 & -2.2 & 0.3 & 2.8 & 5.3 \\
\hline & \multicolumn{7}{|c|}{ Power plant efficiency: $46 \%$} \\
\hline 2.00 & 9.7 & 12.2 & 14.7 & 17.2 & 19.7 & 22.2 & 24.7 \\
\hline 2.25 & 7.7 & 10.2 & 12.7 & 15.2 & 17.7 & 20.2 & 22.7 \\
\hline 2.50 & 5.7 & 8.2 & 10.7 & 13.2 & 15.7 & 18.2 & 20.7 \\
\hline 2.75 & 3.8 & 6.3 & 8.8 & 11.3 & 13.8 & 16.3 & 18.8 \\
\hline 3.00 & 1.8 & 4.3 & 6.8 & 9.3 & 11.8 & 14.3 & 16.8 \\
\hline 3.25 & -0.1 & 2.4 & 4.9 & 7.4 & 9.9 & 12.4 & 14.9 \\
\hline 3.50 & -2.1 & 0.4 & 2.9 & 5.4 & 7.9 & 10.4 & 12.9 \\
\hline
\end{tabular}

given in USD/GJ.

The figures in the individual table fields express the calculated CDS values in USD/MWh. The highlighted coal price level in the range of 2.25-3.0 USD/GJ (9-12 PLN/GJ) is the estimated range of prices of steam coal delivered for the commercial power industry in the coming years.

It can be assumed that the minimum theoretical producer's margin that will cover the costs of electricity generation at the assumed prices of fuel and $\mathrm{CO}_{2}$ and emission allowances.

A comparison of the results of CDS calculations in variants I and II shows how big an impact has power plant efficiency on the achieved result: with higher efficiency, $\mathrm{CO}_{2}$ emissions are lower (emission factor: $0.7680 \mathrm{t} / \mathrm{MWh}$ ). The costs of purchasing fuel required to generate $1 \mathrm{MWh}$ of electricity are also lower with higher power plant efficiency. It is also noteworthy that a change in the price of coal by only $1 \mathrm{USD} / \mathrm{GJ}$ causes a change in CDS in the range of $2-2.5 \mathrm{USD} / \mathrm{MWh}$. 


\section{Conclusions}

Despite the considerable increase in $\mathrm{CO}_{2}$ emissions since 1990 (59\%), in recent years (since 2012), the dynamics of this increase has weakened significantly. In 2015, for the first time, worldwide $\mathrm{CO}_{2}$ emissions decreased slightly compared to the previous year. Three large areas: the U.S., China, and the EU (EU28) are responsible for $52-55 \%$ of global emissions. This share has been constant since 1990 .

Coal combustion is responsible for $40 \%$ of worldwide $\mathrm{CO}_{2}$ emissions, and the share of energy generation in this emission is $42 \%$. The second place in this rating is occupied by transport with a share of $23 \%$.

In the EU, coal combustion and electricity generation entail the need to purchase emission allowances. This situation causes these purchase costs to affect the costs of electricity generation significantly. Emission allowance prices depend on a large number of factors that often have opposite effects. These factors destabilize the market. Among these factors are:

- Increased emission reduction targets in the EU by 2030 and 2050.

- Changes in energy resource prices, especially coal and gas.

- Price relationships between major energy resources (coal/gas).

- Uncertainty of the economic development of the EU and the global economy.

- Planned reform of the EU ETS system.

- Functioning of the Market Stability Reserve (MSR).

- Implementation of the energy efficiency directive by the European Commission.

$\mathrm{CO}_{2}$ emissions caused by coal combustion in power plants entail the need to purchase EUA allowances. The research described in the article shows:

- How current market conditions (variable prices of coal and electricity) shape the profitability of generating electricity from coal.

- How CDS changes as a function of changes in energy and coal prices at the assumed levels of emission and prices of EUA allowances.

The result tables highlight three areas of results where the CDS values are:

- Negative - the prices of electricity do not even cover the costs of fuel and $\mathrm{CO}_{2}$ emission allowances.

- Over $12.5 \mathrm{USD} / \mathrm{MWh}$ (minimum value of the theoretical producer's margin), which allows for covering all electricity generation costs.

- Positive, but below 12.5 PLN/MWh-prices do not cover all fixed costs associated with electricity generation.

A comparison of the results of CDS calculations in two variants shows how big an impact has power plant efficiency on the achieved result: with higher efficiency, $\mathrm{CO}_{2}$ emissions are lower (emission factor: 0.722 $\mathrm{t} / \mathrm{MWh}$ ). The costs of purchasing fuel required to generate $1 \mathrm{MWh}$ of electricity are also lower with higher power plant efficiency. In such case, a power plant can achieve profitability of electricity generation, even with relatively high prices of coal.
Publication prepared within the statutory research of The Mineral and Energy Economy Research Institute, Polish Academy of Sciences.

\section{References}

1. European Association for Coal and lignite, Coal industry across Europe, $6^{\text {th }}$ edition, (2017)

2. Key World Energy Statistics 2016 (Publ. OECD/IEA, Paris, 2016)

3. Statystyka Elektroenergetyki Polskiej (in Polish). (Publ. Agencja Rynku Energii SA, Warsaw, Yearbooks from 2010-2016)

4. B. Klojzy-Karczmarczyk, J. Mazurek, Mineral Resour. Manage. 29, 4, 95-106 (2013)

5. B. Klojzy-Karczmarczyk, J. Mazurek, K. Paw, Mineral Resour. Manage. 32, 3, 111-134 (2016)

6. B. Klojzy-Karczmarczyk, J. Mazurek, J. Mucha, E3S Web of Conferences 10, 00036 (2016)

7. J. Kamiński, P. Saługa, Mineral Resour. Manage. 30, 1, 39-52 (2014)

8. E.J. Sobczyk, J. Kicki, W. Sobczyk, M. Szuwarzyński, Resour. Policy 3, 94-99 (2017)

9. Janssens-Maenhout G., Muntean M. and Peters J.A.H.W., Trends in global $\mathrm{CO}_{2}$ emissions; 2016 Report (Publ. PBL Netherlands Environmental Assessment Agency The Hague, 2016)

10. $\mathrm{CO}_{2}$ emissions form fuel combustion, Highlights 2016 edition (Publ. OECD/IEA, Paris, 2016)

11. Z. Grudziński, Metody oceny konkurencyjności krajowego węgla kamiennego do produkcji energii elektrycznej (in Polish) (Studia, Rozprawy, Monografie 180, 2012)

12. T. Olkuski, Annual Set The Environment Protection 15, 1474-1488 (2013)

13. G. Wojtkowska-Łodej, Polityka Energetyczna Energy Policy J. 17, 3, 269-280 (2014)

14. M. Malec, J. Kamiński, P. Kaszyński, Polityka Energetyczna - Energy Policy J. 19, 1, 21-34 (2016)

15. J. Preś, P. Jankowski, W. Hofman, Analiza rynku handlu uprawnieniami do emisji $\mathrm{CO}_{2}$ (in Polish) (Monthly reports from years 2013-2014, www.handel-emisjami-co2.cire.pl, on-line: 28-042017)

16. www.theice.com, on-line: 28-04-2017)

17. Raport z rynku $\mathrm{CO}_{2}$ (in Polish) (KOBIZE, 58, 2017)

18. Z. Grudziński, K. Stala-Szlugaj, Ann. Set Environ. Prot. 17, 1389-1402 (2015)

19. Sytuacja techniczno-ekonomiczna sektora elektroenergetycznego (in Polish), (Publ. Agencja Rynku Energii SA, Warsaw, quarterly from 20102017)

20. U. Lorenz, Polityka Energetyczna - Energy Policy J. 19, 3, 19-33 (2016) 